\title{
An Investigation into the Relationship between Self-esteem, Proficiency Level, and the Reading Ability of Iranian EFL Language Learners
}

\author{
Kamal Heidari Soureshjani \\ Young Researchers Club Member, Islamic Azad University, Shahrekord Branch, Iran \\ Email: K_tefl_h@yahoo.com \\ Noushin Naseri \\ Shiraz University, International Division, Shiraz, Iran \\ Email: nasseri@hotmail.com
}

\begin{abstract}
The current study aimed at investigating the any probable relationship between Iranian EFL learners' self esteem, proficiency level, and also their reading scores. To do so, 120 male and female Iranian language learners were picked out and grouped into three beginning, intermediate, and advanced-level groups using a reading comprehension test. Then the other instrument of the study, a questionnaire on self-esteem, was employed to measure their degree of self-esteem. Having run two correlations and one regression SPSS programs, the results revealed that there was a significant but weak correlation between the learners' selfesteem and their reading performance. In addition, a strong significant correlation was observed between the proficiency-level of language learners and their self-esteem. Finally, the result indicated that of the two independent variables of the study, it was the proficiency level that was a better predictor of language learners' reading ability. Conducting studies like the present one may contribute effectively on the better teaching of language to learners.
\end{abstract}

Index Terms — self-esteem, proficiency level, reading ability, correlation, regression analysis

\section{INTRODUCTION}

It has been conspicuous through different studies that affective variables play a crucial role in language acquisition. However, in recent years the importance of affective factors has become a matter of debate among language teachers, linguists, and researchers. Scads of studies have been achieved on this issue and most of them approved that affective variables may not be ignored in EFL/ESL learning success or failure. The interest in affective variables in language learning in some modern teaching classes aimed at reducing anxiety and inhibitions and enhancing learners' motivation and self-esteem (De Andres, 2002).

Self-esteem can be simply defined as how we value ourselves. It is how we consider our value to the world around us and how worthwhile we are to others. Self-esteem influences persons' trusts in others, their relationships, and their work. Positive self-esteem gives people the strength and flexibility to take charge of their lives and grow from their mistakes without the fear of being rejected. Positive self-esteem can be manifested through the syndromes such as: optimism, good self-care, non-blaming behavior, etc. At the other side of the coin is low self-esteem which may be realized through signs like: negative view of life, fear of being ridiculed, fear of taking any risk, etc.

Chastain (1988), also maintains that of all learners' variables used for learning a language the most influential are those related to the learner's emotions, attitudes, and personalities. He further continues that the affective domain plays a larger role in developing second-language skills than the cognitive domain because the emotions control the will to activate or shut down the cognitive functions. He believes that if students are not willing to learn, they either will not learn much, or they will not use their maximum capacity to perform well. Moskowitz (1978) states that, there is a relationship between humanistic education and concern for personal development, self-acceptance, and acceptance by others. He actually highlights the important role of making students more human. Moreover, based on humanistic education learning is affected by how students feel about themselves. It is concerned with educating the whole person in all aspects including the intellectual and emotional dimensions.

\section{BACKGROUND TO THE STUDY}

Self -esteem is one of the emotional variables accounted for by many researchers. Alexander (2001), the founder of self-esteem network in Britain, believes that self-esteem is a syndrome, as a set of indicators for mental well-being. The core of self-esteem is an unconditional appreciation of oneself, meaning an appreciation of both our negative and positive potentials in its fullest sense. An acceptance of this enables us to take responsibility for ourselves and become 
accountable for our actions. It also means that we can be more realistic about our achievements and shortcomings. Based on James (1890), it is the sum of our success divided by our pretensions, i.e., what we think we ought to achieve. Therefore, self-esteem can be increased by achieving great success, and maintained by avoiding failure. Raised selfesteem, James then argued could also be achieved and maintained by adopting less ambitious goals. Self-esteem is therefore defined as being competence oriented but also open to change. James (2002) also stated that high self-esteem is not only usually considered good for individuals who have it but it is also good for societies as a whole. The belief is that high self-esteem can inoculate people, especially young people against vulnerability to a wide range of socials ills. Rosenberg (1965) made another important feature to the concept of self-esteem by introducing the notion of "worthiness". Worthiness is whether a person judges him/herself as good or bad and therefore is an evaluative attitude towards oneself. Forming attitudes about oneself is very complicated because it implies some kind of comparison with others, the forming of value judgments and is rooted in a social culture base. Coopersmith (1967) also provided a definition for self-esteem based on which self-esteem is the extent to which an individual believes himself to be able, significant, successful, and worthy. This definition, in fact, is bringing together the James's definition of self-esteem as competence-base and Rosenberg's definition as an evaluation of oneself. Coopersmith, moreover, added the point that self-esteem is important to a person's identity and awareness and that high and low self-esteem would influence a behavior in positive and negative ways respectively.

In line with the above-cited studies, Stevick (1976) rightly asserts that language teacher should make the development of positive attitudes and feelings in language learners as their first and foremost priority. Stevick (1982, p. 27) then maintains that, "fluency depends at least as much on emotional factors as on amount of practice".

Research has shown that the student who feels good about himself is more likely to succeed. Holly (1987) for example compiled a summary of many studies and pointed out that most of these studies indicated that self-esteem is the result rather than the cause of academic achievement. In addition, Heyde (1979) studied the effects of different levels of self-esteem on the performance of an oral production task by American college students learning French as a foreign language. She found that the different levels of self-esteem correlated positively with performance of oral production measures. Results of the studies done by Watkins et. al. (1991) also showed that self-esteem appeared to be an important variable in SLA.

Elmer (2001), in an overview of the current research on the impact of self-esteem on social and personal problems, noted that young people who have very low self-esteem are more likely to show signs of depression. They have, Elmer continued, suicidal thoughts and fail to respond to social influence. If a problem is not biological by itself, then it will almost always be traceable to poor self-esteem (White, 2002).

As to the relationship between the self-esteem and reading skill, Gee (1999) noted that there is an important relationship between affect and reading. Teachers have long been interested in making language learners motivated to read, and it has been recognized that in addition to skills, readers need the inclination to read (Gambrell, 1996). Affective aspects of reading, as maintained by Crammer and Castle (1994), are equal in value to cognitive aspects. Mathewson (1994) also reminds us that cognition and affect are indissolubly connected to reading as they are in all other human endeavors. There is even evidence that in addition to motivating the act of reading, emotional involvement has a significant impact on comprehension (Gaskins, 1996). Recently reading theories call reading an "interactive process (Carrell et al., 1988). Widdowson (1979) describes reading as a combination of textual information and background knowledge of the reader and this knowledge, in turn, may be refined and extended by the new information supplied by the text. Reading is thus viewed as a kind of dialogue between the reader and the texts. Regarding these remarks, although reading is a very important part of every foreign language curriculum, there has been little research on the effect of self-esteem on this skill. Therefore, the current study is an attempt to find the effect of self-esteem on the reading performance of Iranian students of English as a foreign language. in addition to determining the any probable relationship between self-esteem and reading performance, this study also tries to ascertain if the self-esteem as an affective factor, and the reading level of students are interrelated or not.

To be more detailed on the study, the following research questions are addressed in this study:

1. Is there any significant relationship between self- esteem and reading performance?

2. Is there any significant relationship between self-esteem and level of ability of language learners?

3. Which independent variable (self-esteem and level of ability) is a better predictor of reading scores?

Although multitudes of studies have been previously done considering the variable of self-esteem, very few of them investigated its role with regard to reading skill. Consequently, the results of the study can help both teachers and students to pay attention to the effect of self-esteem on language learning and especially on reading to develop positive attitude toward it. Besides, as Brown (2000) rightly pointed out, reading as an important source of input for second language acquisition is very susceptible to be affected by affective variables. Self-esteem, self-confidence, knowledge of one's self, and the belief about one's own capabilities are all examples of affective factors that are very important in accomplishing any activity. Therefore doing studies on them and finding out the relationship that each of them may have with linguistic and cognitive features can add valuable findings to the body of knowledge on better and more effective teaching and learning of a language.

\section{METHOD}




\section{A. Participants}

Altogether 120 Iranian students took part in the study. They were both male and female students and were taking preuniversity courses. Their age ranged from 16 to 23. The participants were divided into three beginning, intermediate, and advanced level groups based on their scores on the placement reading test given to them. After giving the test, it turned out that 42 of the participants were placed in the low, 48 in the intermediate, and finally, 30 of them in the high level of ability groups.

\section{B. Instruments}

Two types of instruments, a reading comprehension placement test and a questionnaire, were utilized to gather the required data. As to the reading comprehension test, it consisted of six reading comprehension passages accompanied by 40 multiple-choice questions. This test was piloted on smaller group of students $(\mathrm{N}=25)$ exclusive of the main participants but similar to them. The reliability of the test turned out to be 0.73 using Cronbach alpha formula. In order to check its content validity, the test was examined by some professors and was confirmed to be valid for the present study purpose.

Regarding the second instrument, the self-esteem questionnaire (See Appendix 1), it was developed by Coopersmith (1967) and consists of 58 items all of which try to measure the degree to which students feel self-esteem during the class. One point with regard to the questionnaire is that 8 items of the questionnaire (items No. 6, 13, 20, 27, 34, 41, 48, and 55) play the role of filter in order to see whether the participants have responded the items with sufficient consideration. Therefore, removing these filters, the rest 50 items are divided into four types of self-esteem: whole selfesteem, social self-esteem, family self-esteem, and lastly, academic self-esteem. This questionnaire was also pre-tested on the same 25 above-cited participants. The Cronbach alpha formula revealed that its reliability was almost 0.76 . Like the first instrument, the questionnaire was also checked and confirmed by the experts to be valid.

\section{Data Collection}

At the beginning of the study the reading comprehension placement test was administered among the participants. The purpose of this test was to divide all the participants into three low, intermediate, and high groups in terms of their reading proficiency level. To do so, the mean and standard deviation of the gained scores, which ranged from 6 to 40 out of 40, were calculated. Those who scored more than one standard deviation above the mean were placed into the high-level group. Those who scored between one standard deviation below and above the mean were considered in the intermediate-level group, and finally, those students whose score were one standard deviation below the mean were placed into the low-level group.

In the next stage of the study that was two days after giving the reading test, the self-esteem questionnaire was distributed among the same students to fill it in. The point with regard to the questionnaire is that the students' responses to each item were scored dichotomously as either zero or one. To be more detailed, for items No. 14, 18, 19, 23, 24, 28, 29, 21, 30, 32, 36, 45, 47, 57, 2, 4, 5, and 10 the YES response will receive one and NO response will receive zero. For the other items the reverse process is applied. That is, for the NO response of the participants, one point and for their YES response no point (zero) were assigned. Therefore, it is obvious that the maximum and minimum score a person may obtain is 50 and 0 respectively. On the whole, each of the students came up with two scores: one for the reading test, and the other for the self-esteem questionnaire.

\section{Data Analysis}

Having gathered the data and in order to analyze them, statistical package for social sciences (SPSS) version 16 in general, and two correlation and a multiple regression in particular were run. The purpose of running these two methods of analysis was to ascertain whether first, there is any relationship between self-esteem and reading performance and also between self-esteem and ability level of language learners; and second, which variable (ability level and selfesteem) is a better predictor of reading scores.

\section{RESULTS}

Having gathered the required data and analyzed them, now in this section the gained results of the study are presented. Table 1 presents the descriptive information of the participants with regard to their reading performance and also self-esteem. The table is conspicuous and needs no further illustration.

TABLE 1.

DESCRIPTIVE STATISTICS

\begin{tabular}{|l|l|l|l|}
\hline \multicolumn{4}{l}{ DESCRIPTIVE STATISTICS } \\
\hline & Mean & Std. Deviation & N \\
\hline selfesteem & 36.0 & 9.8 & 120 \\
readscore & 27.3 & 8.2 & 120 \\
\hline
\end{tabular}

The table that represents the main findings as to the any interrelationship between the level of participants' selfesteem and their reading performance is table 2 . The table clearly shows that since the Pearson correlation equals .53 
and the Sig. value is less than $.05(\mathrm{p}=.01)$, therefore, there is a weak positive and significant relationship between the two variables.

TABLE 2.

CORRELATION RESULTS OF READING SCORE AND SELF-ESTEEM

\begin{tabular}{|c|c|c|c|}
\hline & & selfesteem & readscore \\
\hline \multirow[t]{3}{*}{ selfesteem } & Pearson Correlation & 1 & $.531^{*}$ \\
\hline & Sig. (2-tailed) & & .011 \\
\hline & $\mathrm{N}$ & 120 & 120 \\
\hline \multirow[t]{3}{*}{ readscore } & Pearson Correlation & $.531^{*}$ & 1 \\
\hline & Sig. (2-tailed) & .011 & \\
\hline & $\mathrm{N}$ & 120 & 120 \\
\hline
\end{tabular}

The other aspect of the study seeks the existence or lack of any correlation between the language learners' selfesteem and their proficiency level. Table 3 represents apparently the primary statistics of the two variables.

TABLE 3.

DESCRIPTIVE STATISTICS OF SELF-ESTEEM AND PROFICIENCY LEVEL
\begin{tabular}{|l|l|l|l|}
\hline & Mean & Std. Deviation & N \\
\hline level & 1.9 & .77 & 120 \\
selfesteem & 36.0 & 9.8 & 120 \\
\hline
\end{tabular}

By taking a look at table 4, which represents the correlation findings of the study for the two variables, it can be inferred that first, a significant relationship exists between the reading proficiency level of learners and their self-esteem degree; and second, a strong positive correlation exists between the same variables meaning that the higher the proficiency level of learners, the higher their degree of self-esteem and vice versa.

TABLE 4.

CORRELATION OF SELF-ESTEEM AND PROFICIENCY LEVEL

\begin{tabular}{|ll|l|l|}
\hline & & level & selfesteem \\
\hline level & Pearson Correlation & 1 & $.865^{* *}$ \\
& Sig. (2-tailed) & & .000 \\
& $\mathrm{~N}$ & 120 & 120 \\
\hline selfesteem & Pearson Correlation & $.865^{* *}$ & 1 \\
& Sig. (2-tailed) & .000 & \\
& $\mathrm{~N}$ & 120 & 120 \\
\hline & **. Correlation is significant at the 0.01 level (2-tailed).
\end{tabular}

Having observed a significant and positive relationship between the language learners' self-esteem, reading performance, and language proficiency level, now time is ripe to determine which of the two independent variables of the study (self-esteem and proficiency level) is a better predictor of learners' reading score. The results of regression presented below are a great help. Table 5 is pertaining to the descriptive statistics of the three variables. It consists of the Mean and SD. amounts of each of the variables.

TABLE 5.

\begin{tabular}{|l|l|l|l|}
\multicolumn{5}{c|}{ DESCRIPTIVE STATISTICS OF THE STUDY VARIABLES } \\
\hline & Mean & Std. Deviation & $\mathrm{N}$ \\
\hline eadscore & 27.3 & 8.24 & 120 \\
evel & 1.9 & .77 & 120 \\
elfesteem & 36.0 & 9.81 & 120 \\
\hline
\end{tabular}

Table 6 is the other concerned table which reveals the model summary of the data. What is of out interest in this table is the column labeled $\mathrm{R}^{2}$ also called coefficient of multiple determination which is, in fact, the percent of the variance in the dependent variable explained uniquely or jointly by the independent variables. The mount of $R^{2}$ shows that 47 percent of the variance in the language learners' reading performance is explained by the combinations of the independent variables namely, self-esteem and proficiency level $\left(\mathrm{R}^{2}=.47\right)$. 
TABLE 6

MODEL SUMMARY

\begin{tabular}{|l|l|l|l|l|}
\hline Model & R & R Square & Adjusted R Square & Std. Error of the Estimate \\
\hline 1 & $.828^{\mathrm{a}}$ & .479 & .267 & 7.05879 \\
\hline \multicolumn{4}{|c}{ a. Predictors: (Constant), selfesteem, level }
\end{tabular}

In order to ensure that the coefficient of multiple regression demonstrated by $\mathrm{R}^{2}$ is significant or not, the reported significance of ANOVA table, that is, table 7 needs to be heeded. The table shows that the reported significance is less than the p-value $($ Sig. $=.000)$.

TABLE 7.

ANOVA RESULTS

\begin{tabular}{|ll|l|l|l|l|l|}
\hline Model & & Sum of Squares & df & Mean Square & F & Sig. \\
\hline 1 & Regression & 2258.4 & 2 & 1129.2 & 22.6 & .000 \\
& Residual & 5829.7 & 117 & 49.8 & & \\
& Total & 8088.1 & 119 & & & \\
\hline
\end{tabular}

Finally, table 8 , the coefficient table, presents the information pertaining to every individual independent variable. This table indicates whether and to what extent each of the independent variables has been able to predict the variance in the dependent variable. The first result with the table is that from the two independent variables, the Sig. value is significant just for proficiency variable. It means that just this independent variable was able to predict the variance of the dependent variable $(\mathrm{p}=.00)$. To determine the weighting of this variable on the dependent variable variance, Beta value reveals that one standard deviation unit change in the proficiency level would result in 0.57 units of change in the reading scores $($ Beta $=.057)$.

TABLE 8.

COEFFICIENT

\begin{tabular}{|c|c|c|c|c|c|c|}
\hline \multirow{2}{*}{\multicolumn{2}{|c|}{ Model }} & \multicolumn{2}{|c|}{ Unstandardized Coefficients } & \multirow{2}{*}{$\begin{array}{l}\text { Standardized Coefficients } \\
\text { Beta }\end{array}$} & \multirow[b]{2}{*}{$\mathrm{t}$} & \multirow[b]{2}{*}{ Sig. } \\
\hline & & B & Std. Error & & & \\
\hline \multirow[t]{3}{*}{1} & (Constant) & 18.535 & 2.479 & & 7.475 & .000 \\
\hline & level & 6.157 & 1.017 & .576 & 6.054 & .000 \\
\hline & selfesteem & -.079 & .080 & $\mid-.094$ & -.993 & .323 \\
\hline
\end{tabular}

\section{DISCUSSION}

After presenting the results of the study, $\mathrm{n}$ this section of the paper the afore-cited research questions are presented discussed one by one and then the final comments are mentioned.

1. Is there any significant relationship between self- esteem and reading performance?

The first research question investigates any probable interconnection between the language learners' degree of selfesteem and their reading performance. As it was brought up in the preceding section, the study indicates a significant but weak correlation between the two variables. The study is in contrast to the very many studies that note the important factor of affective factors including self-esteem. Chastain's (1988) is among these studies pointing out that among all the variables affecting the performance of learners affective variables such as self-esteem are more important of other factors like cognitive factors. Gee (1999) also reported an important relationship between affect and reading. The present study, however, implies that other factors may are more important than affective variables. , Stevick (1976) also found out that creating some sense of positive attitudes in language learners as their first and foremost priority. However, the present study indicated that they should pay more attention to linguistic and cognitive aspects of language than affective features.

2. Is there any significant relationship between self-esteem and level of ability of language learners?

This research question addresses the existence of any correlation between the language learners' self-esteem and their proficiency level. The study revealed that there is a positive strong interrelationship between these variables. To reflect cursorily on the statement it seems that the conclusion is right. It is apparent that as the proficiency level of a person increases, that person will be more confident in using the language. There are also some studies confirming this finding. Holly (1987) for example concluded that self-esteem is the result rather than the cause of academic achievement. In addition, Heyde (1979) also approved the above-cited conclusion by asserting that different levels of self-esteem correlated positively with performance of oral production measures. Watkins et. al. (1991) also reported the high importance of self-esteem in SLA.

3. Which independent variable (self-esteem and level of ability) is a better predictor of reading scores? 
And finally, the last research question investigates which of the two independent variables (self-esteem and proficiency level) is a better product of learners' reading performance. It was said that both the independent variables correlate with the reading score of learners. However, it was the proficiency level of learners that correlated more effectively with the reading score of language learners.

\section{CONCLUSION}

The present study aimed at investigating first, is there any relationship between the language learners' self esteem and their reading performance. Second, it explored whether or not there is a correlation between the learners' self esteem and their proficiency level. And finally, the study was also an attempt to ascertain which of the two variables of self esteem or proficiency level is a better predictor of learners' reading performance. The study revealed that with regard to the first purpose of the study, although showed a significant relationship between the learners' self-esteem and their reading scores, this relationship was not so strong. It was also said that in many other studies mentioned in the literature section however, found a strong correlation between the same variables. As to the second objective of the study, the study results imply a significant and strong correlation between the self-esteem and proficiency level of learners. This finding, unlike the first finding of the study, was absolutely consistent with a good deal of previously conducted studies dealing with the same issue. Finally, regarding the last thrust of the study, it was understood that the proficiency level of learners is more effective in determining and predicting the reading performance of language learners than their self-esteem.

The study, albeit the author did his best to conduct a complete study, suffers, however, from some limitations. The first limitation and maybe the most noticeable can be ascribed to the participants of the study. In other words, in order to gain much more reliable information and findings about the study variables there should be carried out other studies with more participants in different contexts. Secondly, this study focused just on the reading skill of language learners. Therefore, more studies need to be carried out with regard to other language aspects so that, more comprehensive conclusions and findings can be made with regard to the role of self-esteem and proficiency level in language learning.

\section{APPENDIX SELF ESTEEM QUESTIONNAIRE}

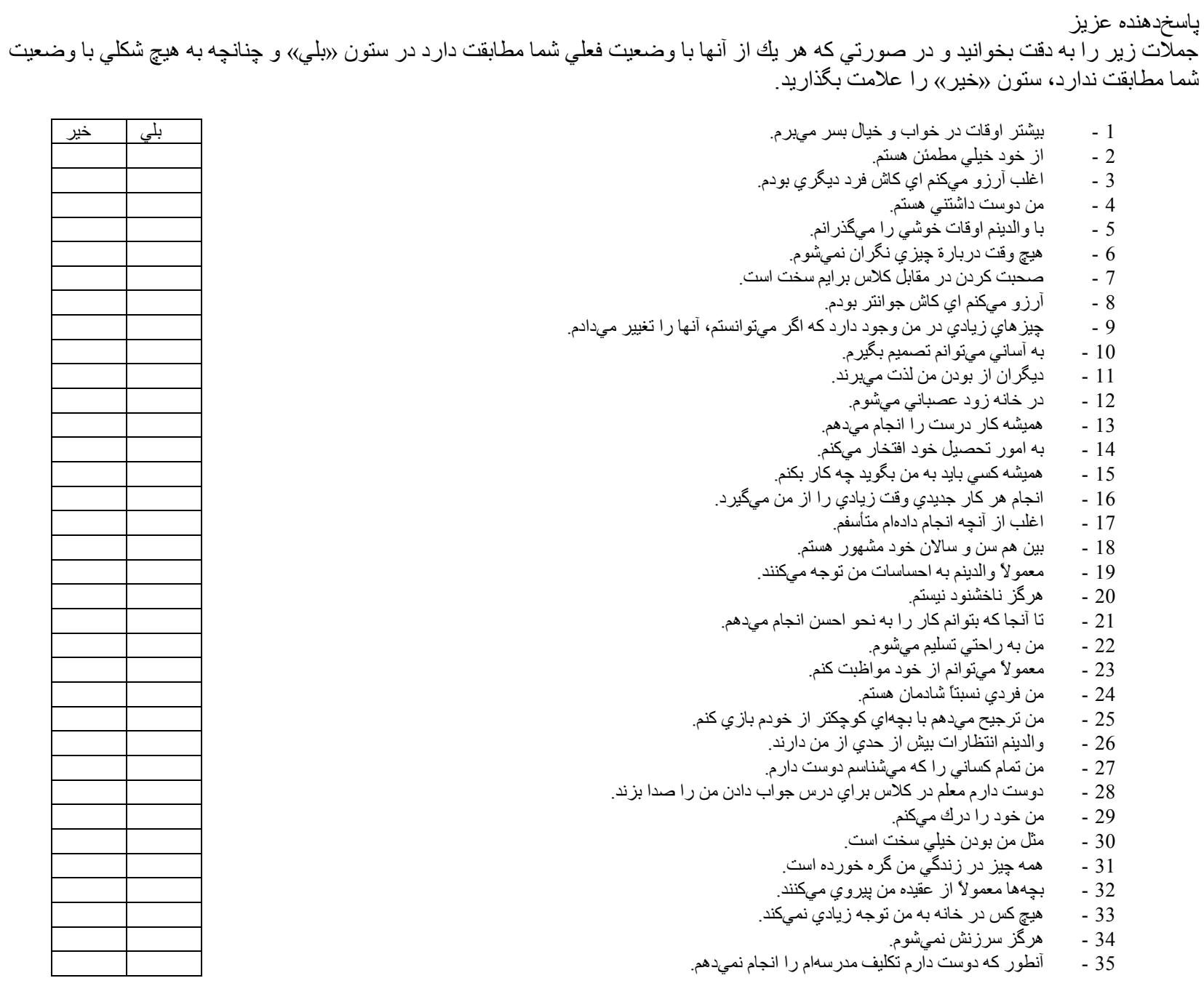




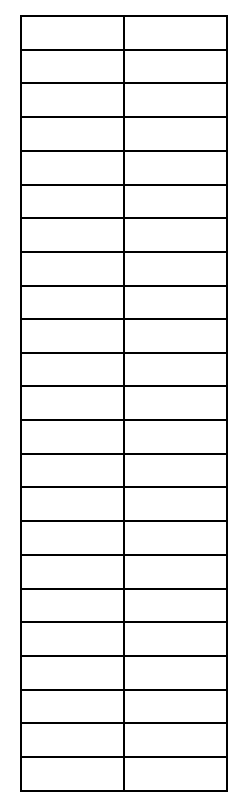

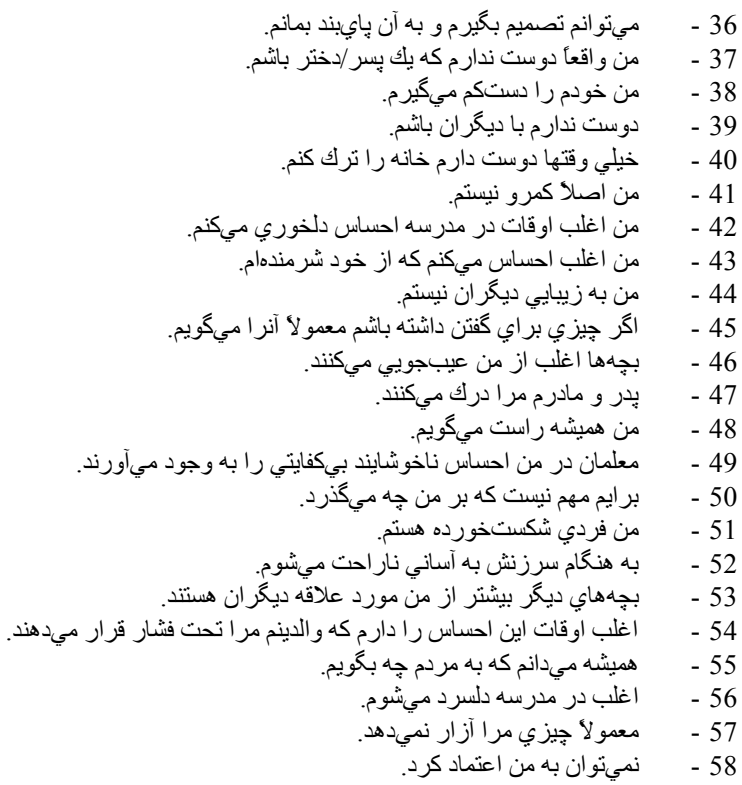

\section{REFERENCES}

[1] Alexander, T. (2001). Defining self-esteem. What is self-esteem and why does it matter? Self-esteem as an aid understanding and recovery. Mental Healthcare, 4(10), 332-335.

[2] Brown, H. D. (2000). Principles of language teaching and learning. (3r ed.) New York: Addison Wesley Longman, Inc.

[3] Carrel, P. L, Devine, J., \& Eskey, D. E. (1988). Interactive approaches to second language reading. Cambridge: Cambridge University Press.

[4] Chastain, K. (1988). Developing second language skills: Theory and practice (3rded.).Englewood Cliffs, NJ: Harcourt Brace Jovanovich.

[5] Coopersmith, S. (1967). The antecedent of self- esteem. San Francisco: Freeman.

[6] Gambrell, L. B. (1996). Creating classroom cultures that foster reading motivation. The Reading Teacher, 50, 14-25.

[7] Cramer, E. H. \& Casttle, M. (1994). Developing lifelong readers In E. H. Cramer \& M. Casttle (Eds.). Fostering the love of reading. (pp. 3-9). Newark, ED: International Reading Association.

[8] Dc Andres, V. (2002). The influence of affective variables on EFL/ESL learning and teaching. The Journal of the Imagination in Language Learning and Teaching, VII, 1-5.

[9] Elmer, N. (2001). Self- esteem. The costs and causes of low self-worth. Joseph Rowntree Foundation: Prentice Hall.

[10] Gaskins, R.W. (1996). That's just how it was: The effect of issue-related emotional involvement on reading comprehension. Reading Research Quarterly, 31, 386-405.

[11] Gee, R. W. (1999). Encouraging ESL Students to Read. TESOL Journal, 9, 3-7.

[12] Holly, W. (1987). Self-esteem: Does it contribute to student's academic success? Oregon. School of Study Council: University of Oregon, Eugene, OR.

[13] Hyde, A. (1979). The relationship between self- esteem and oral production of a second language. Unpublished doctoral dissertation, University of Michigan, MI.

[14] James, K. (2002). Report and literature review into the role of self-esteem as a barrier to learning and as an outcome, available online at: http//www.niace.org.uk/Research/HDE/Documents/self-esteem.pdf.

[15] James, W. (1890). The principles of psychology. In C. Murk (1999), Self-esteem research, theory and practice. London: Free Association Books.

[16] Mathewson, G. C. (1994). Model of attitude influence upon reading and learning to read. In R. B. Ruddell, M. R. Ruddell \& H. Singer (Eds.), Theoretical models and processes of reading (4th ed., pp. 1131-1161). Newark, DE: International Reading Association.

[17] Moskowitz, G. (1978). Caring and sharing in the foreign language class: A sourcebook on Humanistic Techniques. Rowley, Mass.: Newbury House.

[18] Rosenberg, M. (1965). Quoted in Cross KP. (1981). Adults as learners. London: Jossey. Bass.

[19] Stevick, E. W. (1976). Memory, meaning and method. Rowley, Mass: Newbury House.

[20] Stevick, E.W. (1982). Teaching and learning languages. Cambridge: Cambridge University Press.

[21] Watkins, D, Biggs, J, Regmi, M. (1991). Does confidence in the language of instruction influence a student's approach to learning? Instructional Science, 20, 158-177.

[22] White, M. (2002). Magic circle to enhance children's self-esteem. www.globalideasbank.org. (accessed 16/12/2010).

[23] Widdowson, H. G. (1979). The process and purpose of reading. In H. G. Widdowson (Ed.). Exploration in applied linguistics, 171-183. New York: Oxford University Press. 
Kamal Heidari Soureshjani holds M.A in TEFL from Shiraz University and is a Young Researchers Club Member. He taught English courses and IELTS at different institutes in Shiraz and is presently the academic member of Azad University, Shahrekord branch. He has also published papers in journals including IJLS.

Noushin Naseri holds M.A in TEFL from Shiraz University. She has taught different English language courses and also IELTS for several years. She also used to teach at Islamic Azad Universities in Kerman. 